\title{
THE ANALYSIS OF POLITENESS STRATEGEY USED BY THE MAIN CHARACTER OF NOVEL THE SUN ALSO RISES
}

\section{Widyastuti}

\author{
IAIN Salatiga \\ widyastuti.jati@yahoo.com
}

Submission
Track:
Received:
21-10-2019
Available Online:
30-10-2019
Corresponding
Author:
Widyastuti
widyastuti.jati@yahoo.com

\section{ABSTRACT}

The objective of this research is to explore politeness strategies used by the main characters in novel "The Sun also Rises". The analysis is based on the utterances of the main characters. The researcher analyzed the utterances in order to find out the types of politeness strategies used by the main characters. In this research, the researcher used descriptive qualitative by using documentation and observation method of collecting data from the novel. From the analysis of the novel, showed that the main character in The Sun also rises applied the types of politeness strategies, namely bald on record, positive politeness, negative politeness and off record. The main characters also revealed the factors affecting the characters' politeness in speaking, namely language style, register and domain, slang and solidarity, language and gender in their conversation.

Keywords: Politeness Strategy, Character, The Sun Also Rises

\section{INTRODUCTION}

Reading literature work, especially reading novel can give many advantages to the readers. Besides finding moral value, novel can stimulate imagination of the readers. The most important thing in reading the novel is the readers study language. Language is a tool which used to communicate and deliver our idea. Raymond William (1977:21) stated that language is definition of human being in the world which always explains something implicitly and explicitly. It is because language is involved in every aspect of human experience, and creates as well as reflect image of that experience.

The specific study that studied about language called linguistics. There are many branches of linguistics, one of them is pragmatics. Yule (1996) stated that pragmatics is the 
study which concerned the meaning as communication speaker (or writer) and integrated by a listener (or reader). So pragmatics studies about the language and its context in community of speech.

Communication is the way to communicate with other people. Communication has many kind of utterances. One of them is expressive utterance. Expressive utterance is used to express a psychological for example for sympathy, condolences, pleasure, gratitude for thanks, regret for apologies, congratulation. Politeness is behavior that establish and maintain comity. Politeness principle is part of pragmatics that focuses on studying about politeness. Politeness is one of crucial skills for the twenty first century because it is used in daily conversation. As civilized human beings we should certainly think about we uttered, to whom human beings we should certainly think about what we uttered, to whom we uttered or who our partners. It is necessary for us to say polite sentence .Novel is still needed in studying conversation about communication skills especially about politeness. According to Holtgraves (2002: 38) politeness as a technical term, a theory construct evokes as a means of explaining link between language use and social context. Therefore it is important to learn politeness strategies in order to know how to treat other people well and keep someone's feeling. By learning politeness strategies people will get their conversation run well and smoothly.

The researcher focus on novel entitled The Sun also Rises. It deals with a group of aimless expatriates in France and Spain. They were members of the cynical and disillusioned post World War I lost generation, many of whom suffered psychological and physical wounds as a result of the war. The generation of men who took part in the World War I was forever deprived of moral, emotional, spiritual and physical values. Jake Barnes and Lady Bret Ashley were the main characters, typify this generation. This novel is an excellent source since it has various utterances which can be the main source and object to be analyzed. The researcher focuses on the main characters' utterances in the forms of social behavior involving language. The writer analyzes the politeness strategies used by the characters in novel The Sun also Rises since it is interesting to reveal the different ways among the characters interaction by means of communication, especially in the use of politeness strategies and the factors affecting speaking politeness.

\section{Literature Review}




\section{Pragmatics}

Pragmatic is the study of meaning that is using non-linguistics knowledge by considering the intension of the utterance, the context and social word. Pragmatics is the study of language usage (Levinson, 1983). Therefore, pragmatics covers both context-dependent aspect of language structure and principles of language usage and give a little attention to linguistic structure (Levinson, 1983:9). Pragmatics also defines the way of people use language to communicate in conversation based on context of situation. People use direct, indirect imperative speech and other kind of speech to make a good conversation with the hearer. To get a successful conversation, the speaker and hearer have to be careful with all the words that will be said. The hearer will get or interpret what the speaker says as well as possible therefore the conversation run well.

\section{Politeness}

According to Holtgraves (2002: 38) politeness as a technical term, a theory construct evokes as a means of explaining link between language use and social context. Therefore it is important to learn politeness strategies in order to know how to treat other people well and keep someone's feeling. Being polite is not a matter of saying "please" and "thank you" (Holmes, 1995, p. 296). A polite person makes others feel comfortable. Being linguistically polite involves speaking to people appropriately in the light of their relationship to others. The basic concept adopted in this research is politeness developed by Brown and Levinson (1987). They assume that each participant is endowed with what they call face, which is developed into negative face and positive face. Face is the positive social value a person effectively claims for himself by the line others assume he has taken during a particular context. Face, in a sense, is one's situated identity but it is not a specific identity (e.g., sophisticated). Meanwhile, Brown and Levinson (1987) define face as the public self-image that every member wants to claim for himself.

One's negative face includes claims to freedom of an action and freedom from imposition. One's positive face involves the needs for social approval or the want to be considered desirable by at least some others. Brown and Levinson (1987) define politeness as rational behavior aiming at the strategic softening of face threatening acts. A Face Threatening Act (FTA) is a threat to a person's face. Face Threatening Acts, according to Brown and Levinson (1987) are 
acts that by their nature run contrary to the face wants of the intended hearer and/or of the speaker. It is in line with Yule (1996, p. 61) that FTAs are acts which threatens the positive or negative face of the hearer. The speaker, in some ways, threatens the self-image of the hearer. The acts are usually done verbally. For example, if someone asks to borrow money, he is potentially imposing on the person's and so threatening his negative face. Conversely, if someone's apologize to other, he will be threatening his positive face since he is acknowledging having imposed on the person and asking for acceptance of this. It can be concluded that politeness concerns how people maintain interpersonal relationship and involves speaking to participants in order to make a good relationship

\section{Politeness Strategies}

Some acts are threatening to face and require softening, language users try to develop politeness strategies to reduce face loss. Brown and Levinson (1987, p. 92) categorize politeness into four (4) politeness strategies; Bald-on Record, Positive, and Negative Politeness and Off Record. Each strategy will be presented as follows.

\section{Bald-on Record}

According to Brown and Levinson (1987) bald-on record is used in different situations since speakers can have different motives in doing the face threatening acts. They also state that bald on record is the form maximally efficient communication. This strategy is ranked as the most direct strategy. It refers to the expression of an act in the most direct way. It requires no effort from the speakers to reduce the impact of the FTAs. Bald-on-record is likely to shock people to be addressed, embarrass them, or make them feel a bit uncomfortable. "Take some more coffee" or "Do sit down" are the examples of bald on record. Moreover, the speaker can ask the hearer to do something, for example, "Pass me the book!" The strategy can shock the hearer, therefore this type of strategy is usually used when the speakers and hearers have known each other very well and are very comfortable in their environment, such as close friends and family members. Bald-on Record is one strategies in Brown-Levinson politeness principle that in short is the imperative sentence. So direct imperative sentence is very clear example of the use of Bald on Record. The following are the sub strategies of bald-on record politeness strategy. 1) Strategy 1: Great Urgency or Desperation 2) Strategy 2: Speaking as if great efficiency is necessary in 
attention getters 3) Strategy 3: Task-oriented or Paradigmatic Form of Instruction 4) Strategy 4: Sympathetic Advice or Warning 5) Strategy 5: Granting Permission for Something 6) Strategy 6: Invitations 7) Strategy 7: Welcoming 8) Strategy 8: Greetings and Farewells

\section{Positive Politeness}

Holtgrave (2002) state that positive politeness is an approach based strategy. Positive politeness confirms that the relationship of both speakers and hearers are friendly and expressing group reciprocity to minimize the distance among them. According to Brown and Levinson (1987) this strategy attempts to attend the hearers' interests, needs, wants, and goods. Positive politeness addresses the positive face wants of the interaction ants or desire of connection. In Brown and Levinson's view, positive politeness is assumed to be less polite than negative politeness.

The important function of positive politeness is to share some degrees of familiarity with the hearer. It can be considered as the code or language of intimacy. This can be accomplished in various ways, for example, the use of joking and familiar terms of address. "Honey", "luv", and "sister" are the examples of the use familiar terms of address used in group identity makers. The following are the sub strategies of positive politeness strategy. 1) Strategy 1: Notice, attend to a hearer (her or his interests, wants, needs, goods) 2) Strategy 2: Exaggerate (interest, approval, sympathy with hearer) 3) Strategy 3: Intensify interest to a hearer; making good story, draw the hearer as a participant into the conversation. 4) Strategy 4: (Use in-group identity markers); address form, in-group language or dialect, jargon or slang, contraction and ellipsis. 5) Strategy 5: Seek agreement; repetition - agreement may also be stressed by repeating part or all of what the preceding speaker has said 6) Strategy 6: (Avoid disagreement); token agreement, pseudo-agreement, white lies, hedging opinions. 7) Strategy 7: Presuppose/ raise/ assert common ground; gossip, small talk, point-of-view operations, presupposition manipulations. 8) Strategy 8: Joke 9) Strategy 9: Assert or presuppose speaker's knowledge of and concern for hearer's wants. 10) Strategy 10: Offer, Promise 11) Strategy 11: Be optimistic 12) Strategy 12: Include both a speaker and a hearer in the activity 13) Strategy 13: Give (or ask for) reasons 14) Strategy 14: Assume or assert reciprocity 15) Strategy 15: Give gifts to a hearer (goods, sympathy, understanding, cooperation)

\section{Negative Politeness}


According to Brown and Levinson (1987: 131) negative politeness as "the heart of respect behavior" and it is "more specific and focused." The function of this strategy is to minimize imposition on the hearers. It aims at the realization of solidarity. Therefore, it automatically assumes that there might be some social distances or awkwardness in the situation. Using hedges or questions is one of the examples of negative politeness strategy. "Can't we go together?" is the example of minimizing imposition. Negative politeness as repressive action address to addressee's negative face. He wants to have his freedom of action unhindered and his attention unimpeded. Brown and Levinson (1987:132- 211) state that there are 10 sub strategies of negative politeness strategy. 1) Strategy 1: Be direct 2) Strategy 2: Do not assume /presume hearer i. 3) Strategy 3: Be pessimistic about ability or willingness of a hearer to comply to any acts imposed on him. 4) Strategy 4: Minimize the imposition 5) Strategy 5: Give deference. 6) Strategy 6: Apologize; admit the impingement, indicate reluctance, give overwhelming reasons, beg forgiveness. 7) Strategy 7: Impersonalize a speaker and a hearer; per-formatives,. 8) Strategy 8: State the FTA as a general rule 9) Strategy 9: Nominalize to distance the actor and add formality 10) Strategy 10: Go on record as incurring a debt, or as not indebting a hearer.

\section{Off Record}

Brown and Levinson (1987) state that off-record or indirect strategy is done to let speakers figure out the unclear communicative intention. It indicates if the speakers want to avoid their responsibility of doing face threatening acts, they can employ the strategy and let the hearers interpret the intended message. Off-record simply means the statement when one's saying is not directly addressed to the other or 'hints'. "Uh, I forgot my umbrella", means that the speaker wants the intended hearer to lend an umbrella. The meaning of the statement is not directly stated by the speaker and therefore the addressee needs to interpret the meaning. In other words, off record strategy is an indirect politeness strategy where the speaker says something that can be interpreted in many ways by the hearer, depends on hearer's interpretation. The following are the sub strategies of off record politeness strategy. 1) Strategy 1: Give hints 2) Strategy 2: Give association clues 3) Strategy 3: Presuppose 4) Strategy 4: Understate 5) Strategy 5: Overstate 6) Strategy 6: Use tautologies 7) Strategy 7: Use contradictions 8) Strategy 8: Be ironic 9) Strategy 9: Use metaphors 10) Strategy 10: Use 
rhetorical questions 11) Strategy 11: Be ambiguous 12) Strategy 12: Be vague 13) Strategy 13: Over-generalize 14) Strategy 14: Displace hearer 15) Strategy 15: Be incomplete, use ellipsis.

\section{Factors affecting someone's Politeness}

According to Spolsky (1998) identifies four factors which affect people's politeness. There are language and gender, language styles, registers and domains, slang and solidarity. Those four factors determine the use of language concerning politeness between speakers and hearers. Here is the explanation for each factor:

\section{Language and Gender}

Spolsky (1998) states that both men and women share differences in vocabulary. As for children, they tend to pick women's and men's talk as social stereotypes. They assume women's talk has something to do with home and domestic activities, whereas men's talk is associated with the outside world and economic activities.

\section{Language Styles}

A speaker is usually aware of the hearer. People can choose to speak formally or informally according to the person they are addressing. Spolsky (1998), states that people can consciously choose how they try to use language by applying formal or informal expressions to people that they address. According to Spolsky (1998) when one speaks formally, he is engaged in favored and educated norms of their society because he is able to use his language well. Thus, Spolsky (1998) also states the importance of language style is to represent the speaker's sense of identity.

\section{Registers and Domains}

Spolsky (1998) emphasizes that people with particular occupation may create terms for new concepts. People who work at mining environment will be different from people who work at geology in terms of language. Each group can develop terms which may not be familiar for people who do not keep up with the other environment. Thus, a register is a variety of language involving roles and statuses, which is used in certain situations. Social situation is also a key to determine politeness in speaking. Spolsky (1998) states that there is a typical domain which 
defines the way people speak in terms of social situation. Further, he states that domains are named usually for a place or an activity in it. Two common domains are home and work.

\section{Slang and Solidarity}

Spolsky (1998) mentions that slang is used as special kinds of intimate or in-group speech. Slang has social functions as a sign of identity membership and solidarity among people who use it. Spolsky (1998), further, explains that solidarity has a major impact on language. People tend to show group solidarity to others by applying the same language use, such as accent or word choice. The importance of language in establishing social identity is also shown in the case of slang. Slang is a kind of jargon marked by its rejection of formal rules and its marked use to claim solidarity. Slang regularly transgresses other social norms, making free use of taboo expressions. The use words like 'fuck' and 'shit' in public media has become a sign of revolt, depending on one's point of view.

\section{Method}

The researcher used descriptive qualitative methods. Sugiyono (2017:14) states that qualitative research is data in the form of words, schemes, and images. The researcher used qualitative research as the design since the researcher explains the character education descriptively and displays the findings data in terms of words rather than numbers. Qualitative researchers tend to investigate "the quality of relationship, activities, situations, or material" where those four elements as what another type of research is doing. In conducting qualitative research, there are several methods that can be applied. Some of them are content analysis, case study, and discourse analysis. The researcher used discourse analysis as the method in accomplishing this research. Taylor (2001) loosely defines discourse analysis as "the close study of language in use". Primarily, Potter and Wetherell (2001) state discourse analysis espouse the principle that people construct versions of their social world through the instrumentality and functionality of language.

Discourse analysis is more concerned with the analysis of texts and/or utterances within specific socio-cultural context and indicates a method of data analysis that can tell researchers about the discursive construction of a phenomenon (Willig, 2008). Specifically, this method focuses on a power, domination and construction, and reproduction of power in texts and 
conversations, language in social contexts, and interactions (Cohen, Manion, \& Morrison, 2011). The use of discourse analysis for this research was due to the focus of this study which was analyzing the types of politeness strategies and the factors affecting someone in speaking politeness. Since this study dealt with language use in social interactions, discourse analysis was considered as the most appropriate method for this study.

Having analyzed the novel, the researcher categorized the main characters' utterances into four potential types of politeness strategies proposed by Brown and Levinson (1987). Each utterance in the novel was put into each category to help the researcher in analyzing the data. After categorizing the characters' utterances, the researcher identified each utterance to find the factors affecting the characters' politeness in speaking. The researcher employed the theory proposed by Spolsky (1998) related to politeness factors in speaking. Then, the researcher provided explanations on the main character's utterances presented as the examples and associated the findings.

\section{Discussion}

\section{Bald -on Record used in novel The Sun also Rises.}

The subtype of bald-on record politeness used by the main characters were great urgency or desperation, speaking as if great efficiency is necessary in attention-getters, taskoriented or paradigmatic form, sympathetic advice or warning, invitation, greeting and farewell. The following are the results and discussion of bald-on record politeness strategy.

\section{Dialogue 1}

Jakes Barnes was in his room, he felt tired and pretty rotten. Brett came in the room and sat on the bed.

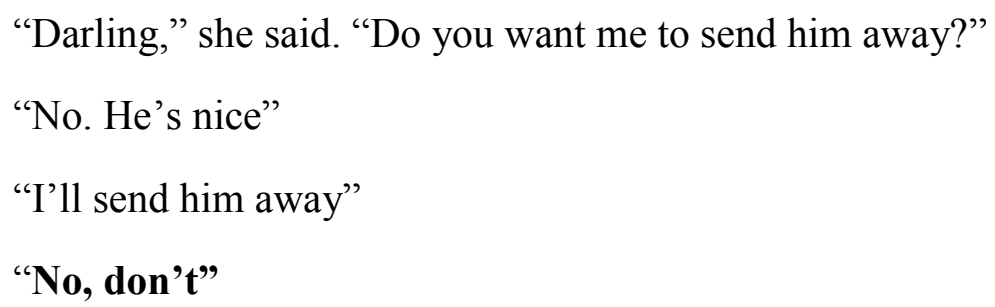

"Darling," she said. "Do you want me to send him away?"

"No. He’s nice"

"I'll send him away"

"No, don't"

(The Sun also rises, page 48) 
The conversation showed that Jake Barnes revealed bald record strategy, number 1, and maximizing efficiency in an urgent situation. Bald-on record politeness strategy is applied because Jake Barnes didn't want Brett asked the count to go away that time. He used "No, don't"' showed that he was in urgent situation.

\section{Dialogue 2}

Jake Barnes was in Paris, he went to café in Montparnasse. At the bar he met his friends Robert Cohn, a writer and Harvey Stone.

"He always get me sore," Cohn said. "I can't stand him".

"I like him" I said. "I'm fond of him. "You don't want to get sore at him."

"I know it," Cohn said. He just gets on my nerves."

"Write this afternoon?"

"No. I couldn't get it going. It's harder to do than my first book."

(The Sun also Rises ,page 39)

In this conversation, Jake Barnes (I) uses Bald-on Record number 2 Speaking as if great efficiency is necessary in attention getters. "Write" means the speaker speaks as if maximum efficiency were very important and the word "write" is used to give attention to hearer in order to hear what the speaker said.

\section{Dialog 3}

When Jake Barnes took bath, he heard the door-bell pull. When he went to the door, he saw Bret and the Count Mippipopolous who was holding a great bunch of roses.

"I don't know whether you like flowers, sir," the count said :but I took the liberty of just bringing these roses"

"Here, give them to me" Bret took them. "Get me same water in this, Jake"

(The Sun also Rises, page 47)

The conversation above showed that Brett Ashley revealed bald-on record strategy number 3, task-oriented utterance. Brown and Levinson (1987) state that this strategy is used to give a task to a hearer. Brett Ashley directly asked Jakes to get some water . the researcher found a lot of subtype number 3 in this novel. 


\section{Dialog 4}

When Jake Barnes got into Bayonne, he met they met a man and his wife who were going on to La Negresse to watch bull-fights in Biarritz.

"Well, I hope you have lots of luck," he said

\section{"Be careful about those bull-fights"}

"May be we'll see you at Biarritz"

(The Sun also Rises, page 75)

Brown and Levinson (1987: 98) state that in doing FTA, the speaker conveys that he or she does care about the hearer. In the conversation above showed that Jake Barnes revealed baldon record strategy number 4, Sympathetic Advice or warning. He wanted to warn the man to be careful because bullfights was dangerous. The word "careful" was used to give attention to what the man was doing so that he did not have a damage from bullfights.

\section{Dialogue 5}

Jakes Barnes and Bill were on the Boulevard. A taxi passed, someone in it waved, then banged for the driver to stop.

"This is Bill Gorton, Lady Ashley"

"I say, I'm just back. Haven’t bathed even. Michael comes tonight."

“Good. Come on and eat with us, and we'll all go to meet him"

(The Sun also Rises, page 63)

The conversation showed that Bill Gorton used bald-on record politeness strategy subtype 6 . He wanted to invite Lady Brett Ashley to eat with them.

\section{Dialogue 6}

Jake Barnes came to Robert Cohn's room before leaving the room he said good bye to his friend.

"Solong Jake," he said "You'll shake hands, won't you"

"Sure. Why not?"

"Well," I said "see you in the morning" 
The dialogue above showed Robert Cohn and Jake Barnes (I) applied bald-on record politeness strategy number 8 , in this case farewell. Although Jake Barnes was angry with Robert Cohn and Robert Cohn apologized when Jakes left the room he said good bye.

\section{Positive Politeness}

According to Brown and Levinson (1987) positive politeness is a redress directed to the positive face, the want to be approved, accepted and desired. This type is usually found to minimize the distance between speaker and hearer. The novel "The Sun also Rises" revealed the subtypes of positive politeness strategy, i.e. exaggerate (interest, approval, sympathy with hearer), Intensify interest to hearer ;making good story, draw the hearer as a participant into the conversation, seek agreement, avoiding agreement, promise, include both a speaker and hearer in the activity. The result and discussion of positive politeness strategy were as follows.

\section{Dialogue 7}

Brett and Jake Barnes (I) danced in Montmartre. The count was sitting at the table smoking and looked at them. When the music stopped, they walked over to the table and the count stood up.

\footnotetext{
"Very nice," he said. "You looked very , very nice"

"Don't you dance, count?"

"No. I'm too old"
}

(The Sun also Rises , page 55)

The dialogue showed that the count used positive politeness strategy number 2, exaggerate (interest, approval, sympathy with hearer). He exaggerated Jake Barnes and Brett's dancing. The word "very, very nice" implied that Jakes Barnes and Bret had amazing dancing.

\section{Dialogue 2}

Bill and Mike came to Jake Barnes room. They told him about Robert Cohn and Bret Ashley.

"You know," Mike went on, "Brett was rather good. She is always rather good. I gave her a fearful hiding about Jews and bull-fighters, and all those sort of people, and do you know what she said: "Yes. I've had such a hell of a happy life with the British aristocracy!" 
The conversation above showed that Mike depicted positive politeness strategy number 3, Intensify interest to hearer, making good story, draw the hearer as a participant into conversation. By using the words "You know", Mike wanted intensify the interest of Jake Barnes by making good story about Brett.

\section{Dialogue 3}

Jake Barnes met Brett Ashley in the bar, they told about Robert Cohn.

"How are you Jake?"

"Fine"

Brett looked at me. "I say," she said “ is Robert Cohn going on this trip?"

"Yes, why?"

\section{"Don't you think it will a bit rough on him?"}

"Why should it?"

(The Sun also Rises, page 71)

The conversation above showed that Brett Ashley used positive politeness strategy number 5, Seek agreement. The sentence "Don't you think it will a bit rough on him" above showed that Brett Ashley said a comment about Robert Cohn that will be a bit rough if he went to the trip. And she wanted Jake agreed with her.

\section{Dialogue 9}

Jake Barnes and Georgette went into restaurant, they talked about Paris.

"No, I don't like Paris. It's expensive and dirty"

"Really? I find it so extraordinarily clean. One of the cleanest cities in all Europe" (The Sun also Rises, page 18)

The conversation above showed that actually Jake Barnes disagree with Georgette but he used positive politeness strategy number 6, avoid disagreement. The sentence "Really? I find it so extraordinarily clean. One of the cleanest cities in all Europe" showed that Jake Barnes avoid disagreement that Paris is dirty.

\section{Dialogue 10}


Jake Barnes ( I ) accompanied Brett Ashley to meet Count Mippipopolous in a bar on the Boulevard Raspail Paris. When the Count was buying champagne, Jake Barnes left them because he got a rotten headache.

"Well, where will I see you?"

“Anywhere around five o'clock"

"Make it the other side of town then"

"Good. I'll be at the Crillon at five"

"Try and be there," I said.

"Don't worry," Brett said. "I've never let you down, have I?"

(The Sun also Rises, page 27)

The conversation above showed that Brett Ashley depicted positive politeness number 10 and 11, Promise and being optimistic. Brett had intention to fulfill Jake Barnes want by saying "I'll be at the Crillon at five". She was optimistic that Jake Barnes believed she never let him down by saying "I've never let you down, have I?". The utterances of Brett made Jake feel comfortable.

Dialogue 11

Jake Barnes and his friend was in Hotel, on the stairs they met Montoya, their friend. They wanted to see Pedro Romero, a bull-fighter.

"Come on," said Montoya. "Do you want to meet Pedro Romero?"

"Fine," said Bill. "Let's go see him"

(The Sun also Rises, page 135)

The conversation above showed that Bill applied positive politeness number 12 , including both speaker and hearer in activity. Bill wanted Jake Barnes and Montoya see Pedro Romero together so he used "Let's"

\section{Negative Politeness}

The negative politeness strategy is less than bald-on record and positive strategy applied by the main characters in novel The Sun also Rises. The subtype of negative politeness which were revealed by main character are be direct, do not presume/assume hearer, being pessimistic, apologizing., 


\section{Dialogue 12}

Jake Barnes and Brett Ashley walked across the wet grass, then they sat on the stone. Brett was so anxious because she wanted to meet Pedro Romero, the bull-fighters although Jake Barnes was her true love.

“Oh, darling, please stay by me. Please stay by me and see me through this." "sure"

(The Sun also Rises page 153)

The dialogue above showed that Brett Ashley applied negative politeness, strategy number 1, be direct. Because Brett was so anxious, she asked Jakes Barnes to accompany her and actually she wanted Jake Barnes helped her to look for Pedro Romero. Brett fell in love with him.

Dialogue 13

Brett Ashley came to Jake Barnes's room. Actually they loved each other, but Jake Barnes was hurt in the war. He was impotent.

\section{"Can't we go together?"}

"No that would be a hell of an idea after we'd just talked it out."

(The Sun also Rises page 49)

The dialogue above showed that Jake Barnes applied negative politeness, strategy 3, being pessimistic. Although they love each other, they couldn't live together. When Jake Barnes said "Can't we go together?" He knew that Brett would refuse it.

\section{Dialogue 14}

Robert Cohn felt very sorry because he hit Jake Barnes. He accused Jake Barnes to go with Brett. Bill told him that actually Brett has gone with Pedro Romero, the bull-fighter. Cohn felt so sorry, so wanted to meet Jakes Barnes to apologize.

\section{"I'm sorry, Jake. Please forgive me"}

"Forgive you, hell"

"Please, forgive me Jake,"

(The Sun also Rises page 161) 
From dialogue above showed that Robert Cohn revealed negative politeness, strategy 6 , apologize. He wanted to apologize to Jake Barnes by saying I'm sorry, Jake. Please forgive me". It means that he was very sorry hit Jakes because he was jealous with him.

\section{Off Record}

Brown and Levinson (1987) state that off record is a communicative act which contain not only one particular intention. So off record strategy is indirect politeness strategy. When the speaker says something, it can be interpreted in many ways by the hearer, depends on the hearer's interpretation. The main characters in novel The Sun also Rises revealed the subtype of record strategy, i.e. give association clues, understate, use contradiction, be ironic and use metaphor. The result of discussion off record politeness strategy as follows.

Dialogue 15

Jakes Barnes (I ) accompanied Brett in hotel, before entered the hotel they said good bye.

“Good-night Brett," I said. "I'm sorry you feel rotten"

"Good night Jake, good night darling. I won't see you again" we kissed standing at the door.

(The Sun also Rises, page 17)

The dialogue above showed that Brett Ashley depicted off record politeness strategy number 2, give association clues. When Brett said "I won't see you again" actually she wanted always with Jake, because he was her true love. But because off Jake's impotent, she couldn't live with him.

Dialogue 16

Before going fishing Jake Barnes (I ) and his friend, Bill had breakfast at the inn. They talked about the profession of Jake as newspaper man after being a soldier in the war.

"No," I said "I just had an accident,"

"Never mentioned that" Bill said

(The Sun also Rises, page 96) 
The dialogue above showed that Jake Barnes depicted off record politeness strategy number 4, understate. Jake Barnes told to Bill that he just an accident. Actually in the war he was hurt that made him became an impotent man.

Dialogue 17

Jake Barnes and Bill talked everything during their breakfast at the inn.

"You are a hell of good guy. Anybody ever tell you, you were a good guy?"

"I'm not a good guy"

"Listen. You are a hell a good guy, and I'm fonder of you than anybody of earth"

(The sun also rises page 97)

From the dialogue above showed that Jake Barnes depicted off record politeness strategy number 7, use contradiction. Jakes Barnes said that he was not a good guy, but actually he was good guy, as Bill said," Listen. You are a hell a good guy, and I'm fonder of you than anybody of earth"

Dialogue 18

After the fiesta of bullfighting was over, Bill and Jakes Barnes parted at the station, the went in through the gate of the train.

"So long, fella" Bill said

\section{"So long, kid!"}

(The Sun also Rises page 192)

From the dialogue above showed that Jake Barnes depicted off record politeness strategy number 8, be ironic. Jake Barnes called Bill "kid", it means that Jakes said the opposite of he means. Kid means male term of address, used with other male.

Dialogue 19

When Jake Barnes was reading, Robert Cohn came and sat on the chair in front of him.

"This is a comfortable café," he said "Did you have a good night, Jake?"

"I slept like a log"

(The Sun also Rises page 84) 
From the dialogue above showed that Jake Barnes depicted off record politeness strategy number 8 , use metaphor by saying "I slept like a log" it means that Jakes Barnes slept very well.

\section{Factors Affecting the Characters' Politeness in Speaking}

Language styles, registers and domains, slang and solidarity, and language and gender are factors that affect people in speaking politeness (Spolsky, 1998). In this research, the researcher found the factors affecting the main characters' politeness in speaking in Novel The Sun also Rises were language and styles, registers and domains, and slang and solidarity. The followings are the discussion of each factor.

\section{Language and Gender}

Spolsky (1998) states that both men and women share differences in vocabulary. The analysis has shown that novel The Sun also Rises reflect gender and power dynamics through the manner authors use language, in their characters. Man did not have domination, it showed from Brett utterances to Jake Barnes "Come on let's dance" Brett said, "Let's go" said Brett, "do give me a cigarette. Even Brett refused when Pedro Romero asked her to grow her hair that made her more womanly "He wanted me to grow my hair out. Me with long hair. I look so like hell". The feminist movement has been going on for years and gender issues have become topical the world over. This in turn reflects on the nature and stature of women in society. .

\section{Language and Styles}

The novel contained informal expressions in the characters' utterances. According to Spolsky (1998) people can consciously choose how they try to use language by applying formal or informal expressions to people that they address. Further, Spolsky (1988) states that one's is likely to conform to the favored and educated norms of the society if the situation is more formal and he or she is giving more attention to the language. Simply put, language style refers to different degree of formality. The characters' utterances in the novel "The Sun also Rises" contained only informal expressions. Most of the dialogue in the novel are located in restaurant, bar or hotel. They talked with their friends that they know well but to keep their friendship and respect to each other they used politeness strategy. 


\section{Registers and Domains}

A register is a variety of language most likely to be used in a specific situation and with particular roles and statuses involved (Spolsky, 1998). A register is marked by choices of vocabulary and of other aspects of styles. Besides, domain is named usually for a place or an activity. Spolsky (1998) states that register and domain belong to social situations which are also a key to determine politeness in speaking. The conversations or the activities of the main characters in the novel mostly took place in the restaurant, bar and hotel.

The topic of the conversation was mostly about the war, writing and fiesta. Most of the time, the conversations took place in the bar, they were drinking, dancing and talking about fiesta. They were a group of aimless expatriates in France and Spain. They are members of the cynical and disillusioned post World War I lost generation, many of whom suffer psychological and physical wounds as a result of the war. Their conversations would run such as "You are happy, all right", "Happy hell”, "Come on, Jake, have a drink, "You are a rotten dancer, Jake. Michael's the best dancer I know" "good night darling, I won't see you again: The rolerelationship included some veteran in World War I, they lived aimless by drinking and dancing. War and love were the common topic of the conversation.

\section{Slang and Solidarity}

Slang is important in establishing a social identity. Spolsky (1998) states that slang is used as special kinds of intimate or in-group speech. Solidarity was represented by Bill when he gave Jake Barnes a compliment about his kind as good guy when Jake felt hopeless. He gave a compliment by saying, "You're good guy, and I'm fonder of you than anybody on earth" It showed that he fully motivated that Jakes Barnes was a good man. Jake Barnes used slang when they parted in the gate to the train. "So long, fella", "So long old kid" . Cohn said "He always gets me sore"By choosing the form of language associated with a specific group, for examples fella, guy (fellow), old kid (male term of address, used with other male), get me sore (get mad) the characters were making a claim to be counted as a member of the same group. In this novel the readers could many words "hell", it belong to slang because it is a kind of jargon marked 
by its rejection of formal rules and its marked use to claim solidarity. Their conversations between Jakes Barnes and Bill were mostly related to war, fishing and bull-fighting.

There was power connection in their relationship. They were still engaged in the same topic and situation. The tendency to use positive politeness strategies, emphasizing closeness between speaker and hearer, can be seen as slang and solidarity.

\section{Conclusions}

The first research result showed that the types of politeness strategies used by the main characters in the novel The Sun also Rises were bald-on-record (direct), positive politeness, and negative politeness and off-record (indirect). The second research result showed that the factors affecting the characters' politeness in speaking were language and styles, registers and domains, and slang and solidarity and language and gender. The types of politeness strategies and the factors affecting the main characters politeness were related. The main characters of the novel "The Sun also Rises" were affected by four factors when they revealed the four types of politeness strategies. Although the main characters of the novel are aimless and immoral people but they have politeness strategy to make others feel comfortable.

\section{Bibiliography}

Brown, P., \& Levinson, S. C. (1987). Politeness: Some universals of language usage. Cambridge Cambridge: Cambridge University Press.

Cohen, L., Manion, L., \& Morrison K. (2000). Research methods in education (5th ed.). London: Routledge Falmer.

Fraenkel, J. R., \& Wallen, N. E. (2006). How to design and evaluate research in education. Boston: McGraw-Hill.

Hemingway, E. (1950). The Sun Also Rises. New York: Charles Scribner's Son.

Holmes, J. (1995). Women, men and politeness. London: Longman. 
Mayers, J. (1985). Hemingway a Biography. New York: Harper \& Row Publishers Inc.

Nurgiantoro, B. (2015). Teori Pengkajian Fiksi. Yogyakarta: Gajah Mada University Press.

Nyoni Tsitsi, Kellerer Katjer (2017). Language and Gender in Selected Shona Novel. IOSR Journal of Humanities and Social Science. (IOSR-JHSS). 22 (9) pp 1-9

Potter, J., \& Wetherell, M. (2001). Unfolding discourse and social psychology. In M. Wetherell, S. Taylor, \& S. J. Yates (Eds.), Discourse theory and practice: A reader (pp. 198-209). London: Sage Publications.

Rani, R. (2014). Sense of Alienation in Ernest Hemingway's The Sun Also Rises. International Journal pf Research (IJR) 1 (5), 964-971.

Rosari Miwita. (2016). Politeness Strategies applied by Characters of The Great Debaters Movie. LLT Journal 9 (1) pp. 19-33

Sugiyono. (2017). Metode Penelitian Kuantitatif, Kualitatif dan R7D. Bandung: Pusat Bahasa Depdiknas.

Spolsky, B. (1998). Sociolinguistics. Oxford: Oxford University Press.

Sutopo, H. B. (2002). Metodologi penelitian kualitatif. Surakarta: Sebelas Maret University Press.

Taylor, S. (2001). Locating and conducting discourse analytic research. In M. Wetherell, S. Taylor, \& S. J. Yates (Eds.), Discourse as a data: A guide for analysis (pp. 5-48). London: Sage Publications.

Widyastuti (2018). The Comparison of Indonesia and American"s Culture in early $20^{\text {th }}$ century through Novel Sengsara Membawa Nikmat and The Sun also Rises. International Conference on Linguistics Proceedings. Pusat Pengembangan Bahasa IAIN Surakarta.

William, R. (1977). Keyword: A Vocabulary of Culture and Society. New York: Oxford University Press.

Willig, C. (2008). Introducing qualitative research in psychology. Berkshire: McGraw-Hill. Yule, G. (1996). Pragmatics. Oxford: Oxford University Press. 